\title{
The Immunogenicity of Insulin Preparation. Antibody Levels before and after Transfer to Highly Purified Porcine Insulin
}

\author{
L. G. Heding ${ }^{1}$, Y. Larsson ${ }^{2}$, and J. Ludvigsson ${ }^{2}$ \\ ${ }^{1}$ Novo Research Institute, Copenhagen, Denmark, and ${ }^{2}$ Department of Paediatrics, Linköping University, Linköping, Sweden
}

Summary. Ninety-two insulin-dependent diabetics (aged 4-20 years, mean \pm SD: $13 \pm 4$ ) with a duration of diabetes from 2 to 17 years $(7 \pm 3)$ were transferred from Lente or NPH $(5 \times$ crystallised insulin) to Monotard insulin (highly purified insulin). Total serum immunoreactive insulin levels and concentrations of antibodies against insulin, porcine proinsulin, a-component and pancreatic polypeptide were determined prior to [I] and at a mean of 220 [II], 460 [III], 830 [IV], and 1170 [V] days after the change. All but two subjects had insulin antibodies (IgG) at the start, with a mean value of $2864 \mu \mathrm{U} / \mathrm{ml}$. There was a significant fall in the mean insulin antibody level between [I] and [II] to $2165 \mu \mathrm{U} / \mathrm{ml}$ $\left(\mathrm{p}<10^{-7}\right)$, followed by an increase between [II] and [III] whereafter a slight decrease was observed being significant between [III] and [IV], as well as between $[\mathrm{IV}]$ and $[\mathrm{V}](\mathrm{p}<0.05)$; some patients showed a constant fall over the entire period, while others showed fluctuations. Total serum insulin showed a similar pattern, with a mean value of $1141 \mu \mathrm{U} / \mathrm{ml}$ at [I] declining to $522 \mu \mathrm{U} / \mathrm{ml}$ at [V]. The percentage fall between [I] and [V] was greater $(54 \%)$ than that in the insulin antibodies $(30 \%)$. Antibodies against acomponent, proinsulin and pancreatic polypeptide were present in $96 \%, 72 \%$ and $41 \%$ of the patients respectively before the change in therapy. There was a decline in these antibodies between each sampling ( $\mathrm{p}$ values between $<10^{-3}$ and $10^{-8}$ ) and, at the end of the investigation antibodies against a-component were above the detection limit in only 4 patients, and none of the patients showed antibodies against proinsulin or pancreatic polypeptide. Thus, removal of the impurities, including the hormonal contaminants of insulin, leads to a slow fall in antibodies to insulin and a much faster disappearance of antibodies against acomponent, proinsulin and pancreatic polypeptide.

Key words: Insulin antibodies, proinsulin antibodies, pancreatic polypeptide antibodies, a-component antibodies, total serum immunoreactive insulin, insulin immunogenicity, insulin-dependent diabetes.

It is well known that treatment of diabetes with insulin preparations purified only by crystallization leads to the formation of considerable amounts of insulin antibodies in nearly all patients [1-4].

In addition, the impurities present in some insulin preparations may lead to the formation of other types of antibodies, such as antibodies against the highmolecular-weight proteins a-component $[5,6]$, proinsulin [6-10], pancreatic polypeptide (PP) [10-12], VIP (vasoactive intestinal peptide) and glucagon $[11,12]$. However, reports so far published are not very extensive. Only one study reported antibodies against the impurities after transfer of the patients from Lente $(5 \times$ crystallised $)$ to Monotard (Monocomponent $=\mathrm{MC}$ ) insulin, but provided no information concerning the antibody levels prior to the transfer [6].

In the present study, a group of diabetic children and adolescents was transferred from Lente or NPH insulins to Monotard insulin. This paper describes the circulating levels of IgG against insulin, a-component, proinsulin and PP and the total amount of immunoreactive insulin (IRI) before and up to 3 years after the transfer.

\section{Materials and Methods}

\section{Patients}

Ninety-two insulin-dependent diabetics, aged 4-20 years at the beginning of the study, were included in the study. No patient had any other chronic disease or was taking steroids during the course of the study. The duration of diabetes varied from 2 to 17 years. Therapy prior to transfer comprised one $(57 \%)$ or two $(43 \%)$ 
Table 1. Number of patients from whom serum was available included in the assays at the different sampling times

\begin{tabular}{|c|c|c|c|c|c|}
\hline $\begin{array}{l}\text { Sampling no. } \\
\text { Days, mean } \\
\text { Days, range }\end{array}$ & $\begin{array}{l}\text { I } \\
0\end{array}$ & $\begin{array}{l}\text { II } \\
223 \\
102-364\end{array}$ & $\begin{array}{l}\text { III } \\
463 \\
316-588\end{array}$ & $\begin{array}{l}\text { IV } \\
834 \\
604-944\end{array}$ & $\begin{array}{l}V \\
1170 \\
1024-1267\end{array}$ \\
\hline $\begin{array}{l}\text { Insulin } \\
\text { antibodies }\end{array}$ & 92 & 89 & 89 & 69 & 62 \\
\hline Total IRI & 91 & 89 & 89 & 69 & 61 \\
\hline $\begin{array}{l}\text { a-component } \\
\text { antibodies }\end{array}$ & 54 & 54 & 54 & 39 & 33 \\
\hline $\begin{array}{l}\text { Proinsulin } \\
\text { antibodies }\end{array}$ & 54 & 54 & 54 & 39 & 33 \\
\hline $\begin{array}{l}\text { PP } \\
\text { antibodies }\end{array}$ & 40 & 40 & 40 & 27 & 25 \\
\hline
\end{tabular}

daily injections of Lente $(70 \%$ of crystalline bovine and $30 \%$ of amorphous porcine insulin) or NPH. The $5 \times$ crystalline insulin in Lente contained approximately $15000 \mathrm{ppm}$ (parts per million by weight) of proinsulin, $1 \mathrm{ppm}$ of $\mathrm{PP}$, whereas the contents of proinsulin in the highly purified insulin used in this study was $\leq 1 \mathrm{ppm}$ and that of $P P \leq 0.01 \mathrm{ppm}$. All patients were transferred to Monotard insulin from one day to another. Blood samples were drawn in the fasting state prior to the morning insulin injection, and serum was stored at $-18^{\circ} \mathrm{C}$ until use. Samples were taken before the transfer (sample [I]) and then at 223 days (range 102-364 days), sample [II]; at 463 days (316-588), sample [III]; at 834 days (604-944), sample [IV]; and at 1170 days (1024-1267), sample [V].

Table 1 shows the number of patients included in each examination. Fewer patients were examined for IgG against a-component, proinsulin and PP due to shortage of serum from the first drawing and the study of these antibodies included only those patients where serum was available from the first three examinations. Total IRI and insulin binding IgG were measured throughout the study while the other antibodies were determined together at the end of the study. All parents and children (or adolescents) were informed of and gave their consent to the change of insulin preparation.

\section{Antibody Determinations}

Total IRI was determined according to [13] and IgG binding of insulin by radioimmunoelectrophoresis [14].

\section{Determination of $\operatorname{Ig} G$ with Affinity to Proinsulin and a-component}

Prior to the determination of proinsulin and a-component binding to IgG, all insulin binding IgG must be removed: $200 \mu \mathrm{l}$ of serum was added to $600 \mu \mathrm{l}$ of a Sepharose-highly purified bovine insulin suspension containing $1 \mathrm{mg}$ of Sepharose-bound insulin per $\mathrm{ml}$. After $20 \mathrm{~h}$ shaking at $4^{\circ} \mathrm{C}$ the bound insulin antibodies were removed by centrifugation at $2000 \mathrm{rpm}$ (Mistral 6L) and the supernatant used for proinsulin and a-component antibody determinations.

\section{Determination of Porcine Proinsulin Binding $\operatorname{Ig} G$}

Fifty $\mu l$ of sepharose-insulin supernatant (see above) was mixed with $50 \mu \mathrm{l}$ of barbital buffer and $50 \mu \mathrm{l}$ of porcine ${ }^{125} \mathrm{I}$-proinsulin
$(125 \mathrm{ng} / \mathrm{ml}, 25 \mu \mathrm{Ci} / \mu \mathrm{g})$ in barbital buffer. After $20 \mathrm{~h}$ at $4{ }^{\circ} \mathrm{C}$ the ${ }^{125} \mathrm{I}$-proinsulin bound to IgG was determined by radioimmunoelectrophoresis as described previously [14]. The amount bound in $\mathrm{ng} / \mathrm{ml}$ supernatant was then calculated. In normal serum a mean nonspecific binding of $0.65 \mathrm{ng} / \mathrm{ml}(\mathrm{SD}=0.28)$ has been recorded. The results are corrected for this nonspecific binding and only values $>1 \mathrm{ng} / \mathrm{ml}(\sim 3 \mathrm{SD})$ were considered positive.

\section{Determination of Porcine a-component Binding to $\operatorname{Ig} G$}

Fifty $\mu 1$ of the sepharose-insulin supernatant was mixed with $50 \mu 1$ of barbital buffer and $50 \mu 1$ of ${ }^{125} \mathrm{I}$-porcine a-component $(1250 \mathrm{ng} /$ $\mathrm{ml}$ ) in barbital buffer, $\mathrm{pH}$ 8.6. The procedure was thereafter the same as that described above. In normal serum the mean nonspecific binding was $32 \mathrm{ng} / \mathrm{ml}(\mathrm{SD}=7)$. The results were corrected for the nonspecific binding in normal serum and values $>25 \mathrm{ng} / \mathrm{ml}(\sim 3 \mathrm{SD})$ were considered positive.

\section{Determination of Porcine Pancreatic Polypeptide (PP) Binding to $\operatorname{Ig} G$}

Fifty $\mu$ l of serum was mixed with $50 \mu$ lof barbital buffer and $50 \mu \mathrm{l}$ of ${ }^{125} \mathrm{I}$-PP (diluted with barbital buffer to $125 \mathrm{ng} / \mathrm{ml}$ ). After incubation as described above, the amount bound to IgG was determined by radioimmunoelectrophoresis. In normal serum the mean nonspecific binding was $0.79 \mathrm{ng} / \mathrm{ml}(\mathrm{SD}=0.14)$. The results were corrected for this nonspecific binding and only values $>0.5 \mathrm{ng} / \mathrm{ml}$ were considered positive.

The statistical evaluation of the differences between the various results on samples at $\mathrm{I}$, and II to $\mathrm{V}$ was performed using the Pearson Rank Test.

\section{Results}

\section{Total IRI and Insulin Antibodies}

Serum total IRI and insulin antibody levels are shown in Figures 1 and 2. Only two patients were free of insulin antibodies at the start. Table 2 shows the mean values and the statistical evaluation (ranges are shown in Figure 1 and 2). The majority (45) of patients had significantly lower, 11 significantly higher and 6 unchanged levels of insulin antibodies 1170 days after transfer. The major fall of both IgG binding and serum total IRI took place within the first interval, after which there was an increase in IgG which fell slightly again later. Total IRI was virtually unchanged between periods [II] and [V].

\section{Antibodies to a-component and Porcine Proinsulin}

The distributions of the a-component and proinsulin antibodies at samplings [I] to [V] are shown in Table 3. Only two patients were free of a-component antibodies, while proinsulin antibodies were found in 


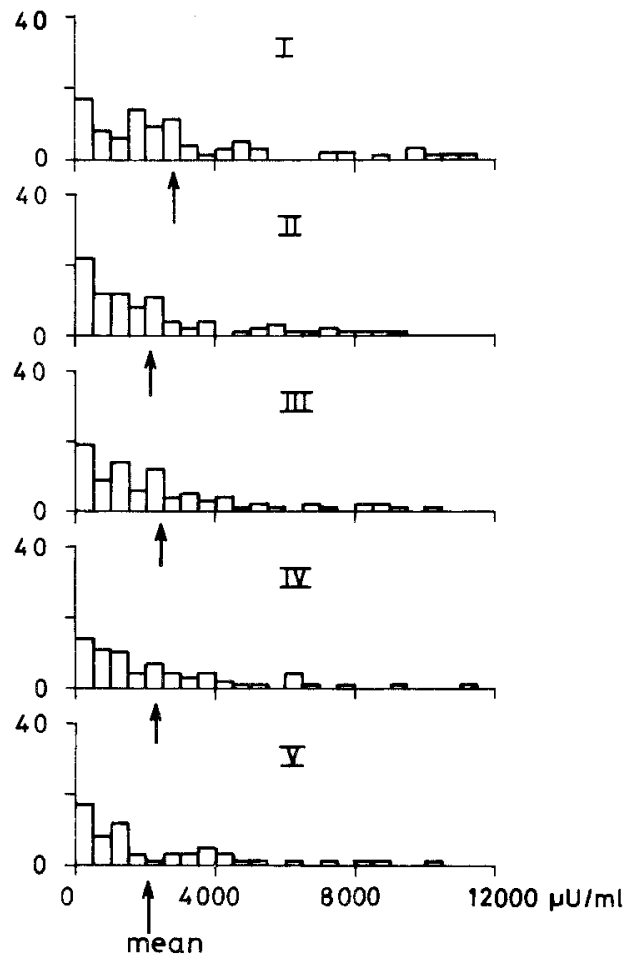

Fig. 1. Insulin binding $\operatorname{IgG}$ in the serum of diabetics before $[\mathrm{I}]$ and at intervals after [II-V] transfer to Monotard insulin from Lente and NPH. Arrows $=$ mean values, the ordinate shows number of patients in each group. Values are given as binding capacity per $\mathrm{ml}$ serum. For definition of sampling times see Table 1

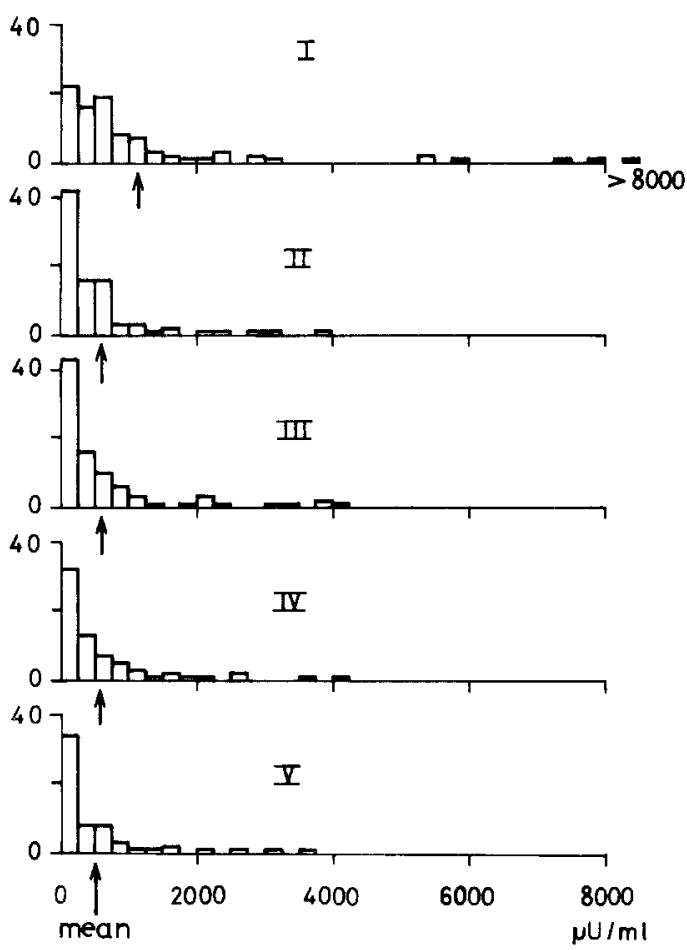

Fig. 2. Total serum IRI in diabetics before [I] and after [II-V] transfer to Monotard insulin from Lente and NPH. Arrows = mean values. The ordinate shows number of patients in each group. For definition of sampling times see Table 1

Table 2. Serum insulin IgG and total IRI at different sampling times

\begin{tabular}{|c|c|c|c|c|c|}
\hline \multirow[t]{2}{*}{ Sampling } & \multicolumn{2}{|c|}{ Serum insulin $\operatorname{IgG} \mu \mathrm{U} / \mathrm{ml}$} & \multicolumn{3}{|c|}{ Total serum IRI $\mu \mathrm{U} / \mathrm{ml}$} \\
\hline & mean & p-value & mean & range & $\mathrm{p}$-value \\
\hline I & $\begin{array}{c}2864 \\
(3004)^{\mathrm{a}}\end{array}$ & $2-11029 \longrightarrow<10^{-7}$ & $\begin{array}{c}1141 \\
(1139)^{\mathrm{a}}\end{array}$ & $10-9120$ & -5 \\
\hline II & 2165 & $6-9039=$ & 598 & $6-8000$ & \\
\hline III & 2440 & $20-10275=$ & 626 & $16-4160=$ & \\
\hline IV & 2330 & $0-11265=$ & 598 & $10-4160=$ & \\
\hline $\mathrm{V}$ & 2109 & $1-10212$ & 522 & $6-3520$ & \\
\hline
\end{tabular}

a Values within brackets indicate mean for the 62 patients who were examined at [V]. For details of sampling times see Table 1 . Statistical analysis by Pearson Rank test

$72 \%$ of the 54 patients examined prior to transfer to Monotard. There was a significant decrease in these types of antibodies from one sampling to the next until levels became undetectable. The only exception was 4 patients who still had a-component antibodies at the final sampling.

\section{Antibodies to PP}

Table 3 shows the results of assays for antibodies to PP. Forty-one percent of the 40 patients had anti- bodies against PP, but these disappeared quickly and were found in only 2 patients at the fourth sampling.

\section{Discussion}

Extensive studies have been published concerning the development of antibodies to insulin after treatment with insulin [1-4], hence the immunogenicity of insulin preparations has often been considered as a matter of induction of insulin antibodies. In fact, 
Table 3. Serum a-component, porcine proinsulin and PP-antibodies at different sampling times. See Table 1 for details of sampling times

\begin{tabular}{|c|c|c|c|c|c|c|c|c|c|}
\hline \multirow[t]{2}{*}{ Sampling } & \multicolumn{3}{|c|}{ Serum a-component antibodies $\mathrm{ng} / \mathrm{ml}$} & \multicolumn{3}{|c|}{ Serum porcine proinsulin antibodies $\mathrm{ng} / \mathrm{ml}$} & \multicolumn{3}{|c|}{ Serum antibodies PP $\mathrm{ng} / \mathrm{ml}$} \\
\hline & mean & range & p-value & mean & range & p-value & mean & range & p-value \\
\hline $\mathrm{I}$ & 172 & $0-326$ & & 9.38 & $0-103.8$ & & 1.59 & $0-8.1$ & \\
\hline II & 69 & $0-159$ & & 1.77 & $0-36.5$ & & 0.36 & $0-2.2$ & \\
\hline III & 45 & $0-130$ & & 0.70 & $0-13.8$ & & 0.23 & $0-1.1$ & \\
\hline IV & 12 & $0-70$ & & 0.40 & $0-4.8$ & & 0.19 & $0-0.8$ & \\
\hline $\mathrm{V}$ & 12 & $0-59$ & & 0.14 & $0-0.4$ & & 0.12 & $0-0.4$ & \\
\hline
\end{tabular}

insulin antibodies are only one of many different types of antibodies, e. g. antibodies against glucagon, VIP, PP, somatostatin, proinsulin, and a-component [5-12] formed following treatment with insulin not purified by extensive chromatographic procedure.

The removal of the hormonal contaminants has been found to abolish the formation of antibodies against VIP, PP, glucagon, and somatostatin [12], as well as a-component and proinsulin $[5,6]$ in patients treated exclusively with MC-insulins. Bruni et al. [6] found a-component antibodies in significantly fewer patients after 5 years of transfer to $\mathrm{MC}$-insulin as compared to the group continued on Lente, but initial values were lacking which make evaluation of the difference impossible. Furthermore, the quality of the MC-insulin used in the studies was inferior to the one used in this study, the latter containing less than $1 \mathrm{ppm}$ of proinsulin, whereas previously the content was between $100-400 \mathrm{ppm}$ [15]. The finding of a-component antibodies in 52 of the 54 patients treated confirms the strong immunogenic nature of the a-component present in $5 \times$ cryst. insulin. Treatment with highly purified insulin of a quality known not to induce antibodies. against a-component [5] led to a quick fall in the levels, but at the third sampling (463 days after transfer) 43 patients still had detectable a-component antibodies. After approximately 2 and 3 years 5 out of 39 and 4 out of 33 had low, but detectable, levels of a-component antibodies.

Proinsulin antibodies were present in 38 of 54 patients prior to transfer. However, these antibodies disappeared quickly as 6 patients only had low levels after 463 days of treatment. PP antibodies were present in about $40 \%$ of the patients and the disappearance of these antibodies was similar to that of proinsulin antibodies. The time required before the levels of antibodies against a-component, proinsulin and $\mathrm{PP}$ became non-detectable was between 1 and 3 years, indicating a continued synthesis of these antibodies at a decreasing rate after transfer to $\mathrm{MC}$-insulin. It can- not be determined whether the continued formation of antibodies is due to a weak continued stimulation of the organism or simply reflects the time it takes before the synthesis stops.

The levels of insulin antibodies follow the patterns described by others, such as Bruni et al. [16]. Most patients showed a decrease after 220 days followed by a small rise and then a slow decline. It is likely that the highly purified insulin used in the present study, despite its low immunogenicity as regards insulin antibodies, is capable of maintaining the stimulation of an organism sensitized by prior treatment to continued antibody production, although the mean rate of production is declining.

The increase in insulin antibody levels observed between samplings [II] and [III] remains obscure. It was not due to problems in the methodology as the daily controls were unchanged. Others have observed the same intriguing finding [16].

The fairly large decrease in total IRI observed between the first and second sampling probably reflects a species change (porcine insulin being bound to a lower degree than bovine insulin), as well as the observed decrease in the level of insulin antibodies. The relation between insulin antibody levels and clinical parameters in these patients is described elsewhere [17].

Acknowledgements. We wish to thank Mrs. Bente Hansen for her skilled technical assistance and Mrs. Birgit Jensen for making the statistical calculations. The study was supported by the Swedish Medical Research Council (project No. 19X-4528).

\section{References}

1. Berson SA, Yalow RS, Bauman A, Rothschild MA, Newerly $\mathrm{K}$ (1956) Insulin- $\mathrm{I}^{131}$ metabolism in human subjects: Demonstration of insulin binding globulin in the circulation of insulin treated subjects. J Clin Invest 35: 170-190

2. Deckert T (1964) Insulin antibodies. Thesis. Munksgaard, Copenhagen 
3. Fankhauser S (1969) Neuere Aspekte der Insulintherapie. Schweiz Med Wochenschr 99: 414-420

4. Galloway JA, Bressler R (1978) Insulin treatment in diabetes. Med Clin North Am 62: 663-680

5. Schlichtkrull J, Brange J, Christiansen AaH, Hallund O, Heding LG, Jørgensen KH, Munkgaard Rasmussen S, Sørensen E, Vølund Aa (1974) Monocomponent insulin and its clinical implications. Radioimmunoassay: Methodology and applications in physiology and in clinical studies. Horm Metab Res 5: 134-143

6. Bruni B, Gamba S, Regis G, Turco GL (1978) Proinsulin and a-component antibodies in diabetics after long-term monocomponent insulin treatment. Diabetologia 14: 165-169

7. Ortved Andersen O (1973) Antibodies to proinsulin in diabetic patients treated with porcine insulin preparations. Acta Endocrinol (Kbh) 73: 304-313

8. Kumar D, Miller LV (1973) Proinsulin-specific antibodies in human sera. Diabetes 22: 361-366

9. Kumar D, Miller LV (1973) The prevalence of proinsulinspecific antibodies in diabetic patients. Horm Metab Res 5: $1-3$

10. Klaff LJ, Vinik AI, Berelowitz M, Jackson WPU (1978) Circulating antibodies in diabetics treated with conventional and purified insulins. S Afr Med J 54: 149-153

11. Bloom SR, West AM, Polak JM, Barnes AJ, Adrian TE (1978) Hormonal contaminants of insulin. Gut 19: 318-322
12. Bloom SR, Barnes AJ, Adrian TE, Polak, JM (1979) Autoimmunity in diabetics induced by hormonal contaminants of insulin. Lancet I: 14-17

13. Heding LG (1972) Determination of total serum insulin (IRI) in insulin-treated diabetic patients. Diabetologia 8: 260-266

14. Christiansen AaH (1973) Radioimmunoelectrophoresis in the determination of insulin binding to IgG. Methodological studies. Horm Metab Res 5: 147-154

15. Schlichtkrull J (1974) Antigenicity of monocomponent insulins. Lancet II: $1260-1261$

16. Bruni B, Bruni Bøcher K, Gamba S, Giolitti A, Rittatore R, Turco GL (1977) Long-term clinical trial with porcine monocomponent Lente insulin (Monotard). Panminerva Med 19: $1-8$

17. Larsson Y, Häger A, Ludvigsson J (1977) Insulin antibodies and therapeutic control in juvenile diabetics after transfer to monocomponent insulin (MCI). Acta Endocrinol [Suppl 209] (Kbh) 85: 51

Received: July 10, 1979,

and in revised form: July 10, 1980

Lise G. Heding

Novo Research Institute

Novo Allé

DK-2880 Bagsvaerd

Denmark 